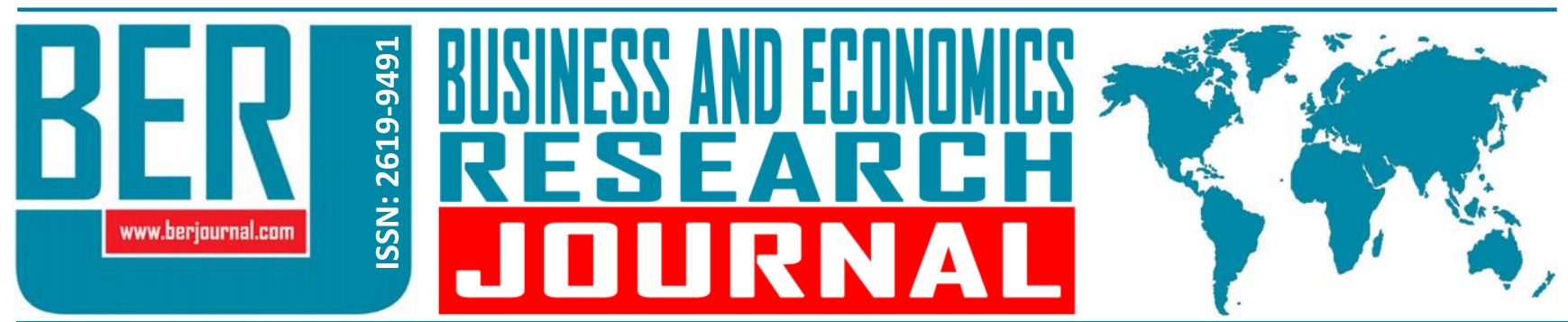

Business and Economics Research Journal Vol. 10, No. 4, 2019, pp. 915-928 doi: 10.20409/berj.2019.210

\section{İş Stresinin İşten Ayrılma Niyetine Etkisinde Örgütsel Bağlılığın Aracılık Rolü}

\section{Nilufer Serinikli ${ }^{\mathrm{a}}$}

Öz: Günümüzde, insanlar zamanlarının büyük bir bölümünü iş yerinde geçirmekte ve dolayısıyla strese maruz kalmaktadırlar. İs stresi çalışanın örgütsel bağlılığını olumsuz etkilemekte ve işten ayrılma niyetine sahip olmasına neden olmaktadır. Bu araştırmanın amacı iş stresinin işten ayrılma niyetine etkisinde örgütsel bağlılığın aracılık rolünü incelemektir. Bu amaç doğrultusunda, Edirne ili ve ilçelerinde faaliyet gösteren otel işletmelerindeki 145 çalışana anket yapılmıştır. Araştırma sonucuna göre, ankete katılan çalışanların iş stresi düzeyinin ve işten ayrılma niyeti düzeyinin düşük olduğu tespit edilmiştir. Buna karşın, çalışanların örgütsel bağlılık düzeyinin yüksek düzeyde olduğu sonucuna ulaşılmıştır. Elde edilen verilerde, regresyon analizlerinden yararlanılmıştır. Regresyon analizi sonucuna göre, iş stresi işten ayrılma niyetini pozitif yönde etkilerken, örgütsel bağlılık işten ayrılma niyetini negatif yönde etkilediği tespit edilmiştir. Ayrıca, araştırma sonuçları örgütsel bağlıığın, iş stresi ve işten ayrılma niyeti ilişkisinde kısmi aracılık rolüne sahip olduğu görülmüştür.

\section{The Mediating Role of Organizational Commitment in the Effect of Job Stress on Turnover Intention}

\begin{abstract}
Today, people spend most of their time in the workplace and therefore are exposed to stress. Job stress negatively affects organizational commitment of employee, but causes lead to employee's having intention to leave. The aim of this study is to study the mediating role of organizational commitment on the effects of job stress and turnover intention. For this purpose, a survey of 145 hotel employees in the city center and districts of Edirne was conducted. The study shows that the level of job stress and turnover intention of employee participating the survey is low. On the other hand, it is concluded that the level of organizational commitment of employees is high. Regression was used for the data analysis. The results of the regression analysis showed that the job stress affected the turnover intention in a positive way, while the organizational commitment affected it in a negative way. The results also indicated that organizational commitment seemed to have a partial mediating role on the relationship between job stress and turnover intention.
\end{abstract}

Anahtar Sözcükler: Örgütsel Bağılıık, İşten Ayrılma Niyeti, İş Stresi, Otel Çalışanları

JEL: D23, L20, M19

$\begin{array}{ll}\text { Geliş } & : 11 \text { Mart } 2019 \\ \text { Düzeltme } & : 08 \text { Mayıs } 2019 \\ \text { Kabul } & : \text { 13 Haziran } 2019 \\ \text { Tür } & : \text { Araştırma }\end{array}$

Keywords: Organizational Commitment, Turnover Intention, Job Stress, Hotel Employees

JEL: D23, L20, M19

Received : 11 March 2019

Revised : :08 May 2019

Accepted : 13 June 2019

Type : Research 


\section{Giriş}

Artan küresel rekabet sonucunda, çalışanlar tüm işletmeler için vazgeçilmez bir unsur haline gelmiştir. İ̧letmelerin uzun vadede varlıklarını sürdürebilmeleri ve piyasadaki rekabetçi konumlarını koruyabilmeleri ancak çalışanlar sayesinde gerçekleşmektedir. Bu nedenle, işletmelerin bedenen ve ruhen sağlıklı, mutlu ve dinamik çalışan yapısına ihtiyacı vardır (Karahan, 2009). Çalışanların, gün içerisinde geçirdikleri zamanının önemli ve büyük bir bölümü iş yerinde geçmektedir. İ̧̧ yerinde yaşanan olumsuz durumlar çalışanlar üzerinde strese neden olabilmektedir. Stres, çalışanların davranışlarını, performansını, iş tatminini ve örgüte olan bağlılıklarını doğrudan etkilemektedir. İş stresinin etki ettiği bir diğer önemli konu da çalışanların işten ayrılma niyetidir. Çalışanların aşırı düzeyde iş stresine maruz kalmaları, onların işine ve iş yerine karşı olumsuz düşüncelere sahip olmalarına ve bunun sonucunda da çalışanların işten ayrılmaya niyet etmelerine neden olabilmektedir. Bu nedenle, işletmelerin stres kaynaklarını asgari düzeye indirmek için, çeşitli önlemler almaya başlamaları giderek önemli hale gelmeye başlamıştır (Savaş ve Erol, 2017).

Literatürde, çalışanların iş stresinin işten ayrılma niyetini etkilediğini ileri süren birçok çalışma mevcuttur. Örneğin, İzmir'de dört ve beş yıldızlı otellerde çalışan garsonlara ve aş̧̧ıbaşılara yönelik yapılan çalışmada stres kaynaklarının (bireysel, iş yükü ve iş yerinin fiziksel özellikleri) işten ayrılma niyetini pozitif yönde etkilediği sonucuna ulaşılmıştır (Onay ve Kılıcı, 2011). Aynı şekilde farklı sektörlerde iş stresi ile işten ayrılma niyetini inceleyen çalışmalarda (Noor ve Maad, 2008; Qureshi vd., 2013; Tekingündüz ve Kurtuldu, 2015) da iş stresinin işten ayrılma niyetini anlamlı olarak etkilediği tespit edilmiştir. Buna karşın, Saltık (2016) İstanbul'da dört ve beş yıldızlı otel çalışanlarına yönelik yaptığı çalışmada, iş stresinin işten ayrılma niyeti üzerinde herhangi bir anlamlı etkisinin olmadığı sonucuna ulaşmıştır.

Çalışanların iş stresleri ile örgütsel bağlılıkları arasındaki ilişkiyi inceleyen çalışmalarda (Uzun ve Yiğit, 2011; Alipour ve Monfared, 2015; Tekingündüz, Top ve Seçkin, 2015), çalışanların iş veya iş yerinden dolayı yaşadıkları aşırı stresin, onların örgüte olan bağıııklarını negatif yönde etkilediği iddia edilmektedir. Başka bir çalışmada ise, iş stresinin örgütsel bağ|ııı̆ı pozitif yönde etkilediği tespit edilmiştir (Mojtabazadeh, Miarkolaei ve Miarkolaei, 2016).

Literatürde değişkenlerin (iş stresi, örgütsel bağlılık ve işten ayrılma niyeti) ikili olarak ilişkilerini inceleyen çok sayıda çalışma olduğu gözlenmiş̧ir. Buna karşın, iş stresi ile işten ayrılma niyeti arasındaki ilişkide örgütsel bağlıığın aracılık rolünü inceleyen çalışmaya hiç rastlanmamıştır. Bu durum bu alanda bir eksiklik olarak görülmekte olup, bu çalışmanın yapılmasına temel teşkil etmektedir. Bu doğrultuda araştırmanın amacı, iş stresinin işten ayrılma niyeti üzerindeki etkisinde örgütsel bağlıı̆ın aracılık rolünün olup olmadığını saptamaktır.

\section{2. İ̧ Stresi}

Stres kavramı ilk kez Selye (1977) tarafından "vücudun herhangi bir dış talebe verdiği özel olmayan tepki" olarak tanımlanmıştır (aktaran: Kılıç, Tunç, Saraçı ve Kılıç, 2013: 19). Stres, insanların huzuru için bir tehdit olarak algılanan olaylara karşı gösterilen belirgin olmayan fizyolojik ve psikolojik bir tepkidir (Gürel, 2016). Ayrıca stres kişide oluşan kısıtlamalar, istekler ve fırsatlarla ilgili olup, insanın ruh yapısının tümünü etkileyen ve kontrol edilemeyen bir tepkidir (Yirik, Ören ve Ekici, 2014). İ̧̧ stresi ise, çalışanın çevresi ile olan etkileşimi sonucunda ortaya çıkan gerilim durumu olarak tanımlanmaktadır (Efeoğlu ve Özgen, 2007). Amerika Ulusal iş̧ Güvenliği ve Sağlığı Kurumu iş stresini, "işten kaynaklı taleplerin çalışanın yeteneği, kaynakları veya ihtiyaçları ile uyuşmama durumunda ortaya çıkan zararlı fiziksel ve duygusal tepkiler" olarak tanımlamaktadır (Yenihan, Öner ve Çiftyıldız, 2014). Kısaca, çalışanların iş ortamında yaşadıkları strese "iş stresi" denir. (Turunç ve Çelik, 2010).

Stres, kişilerin durağan yaşantılarında birden bire ortaya çıkan bir durum olmayıp, kişilerin günlük olarak yaşadıkları veya karşılaştıkları olaylardan dolayı ortaya çıkan bir durumdur. Örneğin kişilerin diğer insanlarla veya çevresi ile olan etkileşimleri, şahit oldukları herhangi bir olay, okudukları (kitap, gazete gibi) ve izledikleri herhangi bir şey kişilerde stres yaratabilmektedir (Şahin, 2014). 
Stres, genel olarak bazı şeylerden memnuniyetsizliği ifade etmektedir. Ancak, her stres olumsuz olarak nitelendirilmemelidir. Aksine, belirli miktar stres kişilere enerji verebilir ve hatta kişiyi motive edebilir. Bazı uzmanlar, ılımlı stresin çalışanların daha yüksek performansla çalıştıklarını ileri sürmektedirler (Büyükbeşe, 2013). Ancak, aşırı ve uzun süreli stres psikolojik, bilişsel, davranışsal ve fiziksel bozukluklara neden olmaktadır. Bu bozukluklar, bir yandan çalışanların performansını (Zincirkıran, Çelik, Ceylan ve Emhan, 2015), örgüte bağııı̆̆ını, verimliliğini, iş tatminini vb. azaltırken, diğer yandan çalışanların işe devamsızlığını, iş kazalarını, iş ilişkilerinde yaşadığı gerginliği, işten ayrılma niyetini, şikâyet ve taleplerini vb. arttırmaktadır (Uzun ve Yiğit, 2011).

Literatürde iş stresinin örgütsel bağlılık, işten ayrılma niyeti, iş tatmini (Gül, Oktay ve Gökçe, 2008), örgütsel özdeşleşme, örgütsel destek, iş performansı (Turunç ve Çelik, 2010), örgütsel sessizlik (Kılıç vd., 2013), iş-aile çatışması (Gürel, 2016) ve depresyon (Savaş ve Erol, 2017) vb. kavramlarla ilişkilendirildiği görülmektedir.

\section{3. Örgütsel Bağ|ılık}

Örgütsel bağlılık, çalışanın örgütün amaç ve ilkelerini benimsemesi, kendini örgütün bir parçası olarak kabul etmesi, örgüt ile kendi çıkarlarını bir görmesi olarak tanımlanmaktadır (Demir ve Öztürk, 2011). Başka bir tanıma göre örgütsel bağ|ııı, çalışanın işine duyduğu ilgiyi, sadakati ve örgütün değerlerine karşı duyduğu inancı ifade etmektedir (Çekmecelioğlu ve Pelenk, 2015). Allen ve Meyer'e (1990) göre örgütsel bağllık bireyin örgüte olan psikolojik bağ|ılığı olup, bu bağlılık duygusal bağ|ı।ık, devamlılık bağ|ılığı ve normatif bağ|ılık olarak üç boyuttan oluşmaktadır (Allen ve Meyer, 1990).

Işletmelerin, amaçlarını gerçekleştirebilmek ve uzun süre hayatta kalabilmek için çalışanlarının bağlııklarına ihtiyaçları vardır (Emhan, Kula ve Töngür, 2013). Örgütsel bağ|ıık, örgütte çalışanları problem yaratan değil, problemlere çözüm getiren insanlar haline dönüştürmektedir. Bu nedenle örgütler çalışanlarının bağılıı̆ını artırmak istemektedirler. (Bozkurt ve Yurt, 2013). Örgütsel bağlılığı artan bir çalışanın örgüte ve üretime katılımı, örgütte kalma isteği, performansı, diğer çalışanlarla olan iyi ilişkileri, sorumluluk duygusu, işte tatmin düzeyleri artarken (Yalçın ve İplik, 2005), işe geç gelme, devamsızlık yapma, stres gibi istenmeyen sonuçların da azalmasına neden olmaktadır (Doğan ve Kılıç, 2007). Ayrıca örgütsel bağlılığı artan bir çalışanın işten ayrılma niyeti de düşük oranda gerçekleşmektedir (Allen ve Meyer, 1990).

Ülkemizde örgütsel bağlılık kavramı ile ilgili farklı sektörlerde yapılan araştırmalarda, örgütle özdeşleşme, iş stresi, iş tatmini, liderlik, örgütsel adalet, performans, örgüt kültürü, motivasyon, örgütte kalma niyeti vb. kavramlarla ilişkilendirilmiştir (Efeoğlu ve Özgen, 2007; Gül vd., 2008; Demir ve Öztürk, 2011; Karavardar, 2015; Tekingündüz ve Kurtuldu, 2015; Zincirkıran vd., 2015; Kerse, 2016; Sökmen ve Şimşek, 2016).

\section{4. İşten Ayrılma Niyeti}

İ̧̧ten ayrılma niyeti, Rusbult ve arkadaşları (1988) tarafından "çalışanların iş koşullarından tatminsiz olmaları durumunda göstermiş oldukları yıkıcı ve aktif eylemler" olarak tanımlanmaktadır (aktaran: Gül vd., 2008). Başka bir tanıma göre işten ayrıma niyeti, çalışan kişilerin mevcut iş yeri koşullarından duydukları memnuniyetsizlik ve dolayısıyla işlerinden ayrılmayı düşünmeleridir. İşten ayrılma niyeti, çalışanın istifa etmeden önceki son adımı olarak tanımlanmaktadır (Yıldırım, Erul ve Kelebek, 2014).

Çalışanın işten ayrılma niyetinin, işten ayrılma davranışına dönüşmesi belli bir süreçte gerçekleşmektedir. Bu süreç birçok unsurdan etkilenmektedir (Seyrek ve İnal, 2017). Genel olarak işten ayrılma niyetine etki eden unsurlar yaş, cinsiyet, eğitim, kişilik özellikleri, ücret, ödül, görev süresi, istihdam algıları, sendika üyeliği, beklentilerin karşılanmaması, alternatif iş olanakları, yöneticilerin davranışları vb. olarak sıralanabilir (Cotton ve Tuttle, 1986). Rusbult ve Farrell (1983) göre her ne kadar ödül, ücret, yaş, cinsiyet, alternatif iş olanakları gibi unsurlar işten ayrılma niyetini etkilese de, örgütsel bağlılık işten ayrılma niyetini doğrudan ve güçlü bir şekilde etkilemektedir (Rusbult ve Farrell, 1983). Bunun yanında iş tatmini, örgütsel destek, örgütsel özdeşleşme, motivasyon, iş stresi ve tükenmişlik gibi unsurlar da işten ayrılma niyetini etkilemektedir (Çakır ve Ceylan, 2005; Gül vd., 2008; Turunç ve Avcı, 2011; Sökmen ve Şimşek, 2016). 
Çalışanın işten ayrılması, işletmeye ağır maliyetlerin (yeni personel alımı, yeni personelin eğitimi, yeni personel ve eski personelin uyumu, finansal maliyelerde artış, nitelikli çalışan kaybı, eski personelde moral bozukluğu ve performans düşüklüğü gibi) yüklenmesine neden olmaktadır (Lambert ve Hogan, 2009). Bunun yanında, çalışanlarda yeni bir iş arama, gelirinde düzensizlik, psikolojik ve ailevi sorunlar, yeni işe uyum sağlayamama gibi sorunlar ortaya çıkmaktadır. Yaşanan bu sorunların ortadan kaldırııması için çalışanın işten ayrılma niyetinin nasıl ortaya çıktığı ve bu niyetin ortaya çıkmasında hangi faktörlerin etkili olduğu tespit edilmelidir. Daha sonra, bu niyetin ortadan kaldırılması için ne/nelerin yapılması gerektiği ve hangi tedbirlerin alınması gerektiği belirlenmelidir. Ancak, o zaman söz konusu sorunlar ortaya çıkmadan önlenmiş olacaktır (Çiftçi, Meriç ve Meriç, 2015).

\section{Araştırmanın Hipotezleri ve Modeli}

Işten kaynaklı talepleri karşılamakta güçlük çeken çalışanlar, zamanla iş stresi yaşamaktadırlar. İş stresi yaşayan çalışanların iş tatmini, bağlılığı, performansı, verimliliği ve işten ayrılma niyeti doğrudan etkilenmektedir (Yenihan vd., 2014).

Literatürde çalışanların iş stresleri arttıkça işten ayrılma niyetlerinin de o oranda artacağını ortaya koyan birçok çalışma mevcuttur. Bu çalışmalardan bazıları şunlardır: Akova vd. (2015) tarafından İstanbul'da faaliyet gösteren beş yıldızlı otel işletmelerinde görev yapan otel yöneticisi ve çalışanlarına yönelik çalışma yapılmıştır. Yapılan çalışmanın sonucunda, iş stresi ile işten ayrılma niyeti arasında istatistiksel olarak yüksek derecede anlamlı ve pozitif yönlü bir ilişkinin olduğu tespit edilmiştir. Gök vd. (2017) tarafından İzmir'de beş yıldızlı otel işletmelerinde çalışan 274 personele yönelik yapılan çalışmada, iş stresi ile işten ayrılma niyeti arasında pozitif yönlü ilişki olduğunu ve iş stresinin artması ile çalışanların gönüllü işten ayrılma niyetinin arttığını ortaya koymuşlardır. Bunun yanında Arshadi ve Damiri (2013) tarafından İran'da faaliyet gösteren Ulusal Sondaj Şirket çalışanlarına; Iqbal vd. (2014) tarafından akademisyenlere; Savaş ve Erol (2017) tarafından okul müdürleri, müdür yardımcıları ve öğretmenlere; Yenihan vd. (2014) tarafından otomotiv sektörü çalışanlarına; Türker (2013) tarafından banka çalışanlarına yönelik yapılan çalışmalarda da iş stresinin işten ayrılma niyetini pozitif yönde etkilediği sonucuna ulaşılmıştır. Yapılan çalışmalar ve kavramsal çerçevede edinilen bilgiler doğrultusunda, çalışanların iş stresinin işten ayrılma niyetini pozitif yönde etkileyeceği beklenmektedir. Buradan hareketle çalışmada aşağıdaki alternatif hipotez önerilmiştir.

H1a: Çalışanların iş stresinin işten ayrılma niyeti üzerinde pozitif bir etkisi vardır.

Yapılan çalışmalarda, çalışanların işinde veya iş yerinde yaşadığı aşırı stres çalışanların örgüte olan bağlıııklarını azalttığı ileri sürülmektedir. Çeşitli sektörlerde yapılan çalışmalarda iş stresinin örgütsel bağlılığı negatif yönde etkilemekte olduğu tespit edilmiştir (Sökmen ve Şimşek, 2006; Lambert ve Paoline, 2008; Atay, 2012; Nazım ve Kakakhel, 2013; Garg ve Dhar, 2014; Bhatti, Bhatti, Akram, Hashim ve Akram, 2016). Araştırmaya konu olan otel işletmeleri açısından iş stresi ile örgütsel bağlılık arasındaki ilişkiyi inceleyen çalışmalar mevcuttur. Bu çalışmalar; Akpulat vd. (2016) tarafından turizm işletme çalışanlarına yönelik yaptıkları araştırmada, iş stresi ile örgütsel bağlılık arasında düşük düzeyde negatif anlamlı bir ilişki olduğu, çalışan personelin çalıştıkları destinasyonlara göre iş stresinde farklılaşmanın olmadığı, ancak örgütsel bağlıııkta bir farklılaşma olduğu sonucuna ulaşılmıştır. Düzgün (2014) tarafından beş yıldızlı otel çalışanlarına yönelik yapılan çalışmada iş stresi ile duygusal, devamlılık ve normatif bağlılıkları arasında negatif yönde anlamlı bir ilişki olduğu tespit edilmiştir. Dolayısıyla, çalışanlarının iş stresinin örgüte bağlılıklarını negatif yönde etkileyeceği beklenmektedir Buradan hareketle çalışmada aşağıdaki alternatif hipotez önerilmiştir

H1b: Çalışanların iş stresinin örgütsel bağlılıkları üzerinde negatif bir etkisi vardır.

Literatürde, örgütsel bağııı̆̆ın artması ile işten ayrılma niyetinin ya azalacağı ya da ortadan kalkacağı ifade edilmektedir. Bu kapsamda örgütsel bağlılı̆ın işten ayrılma niyetine olan etkisini belirlemek amacıyla literatürde çok sayıda araştırmaya rastlanmıştır. Yapılan çalışmalarda, örgütsel bağlılık işten ayrılma niyetini negatif yönde etkilemektedir (Çakar ve Ceylan, 2005; Sökmen ve Şimşek, 2006; Gül vd., 2008; lqbal vd., 2014; Akyüz ve Eşitti, 2015; Pham ve Pham, 2016). Örgütsel bağlılı̆ın işten ayrılma niyeti ile ters yönlü ilişkisi, iş gören devir oranının azalmasını dolayısıyla da nitelikli insan kaynağının örgütte tutulmasını sağlamaktadır (Gürbüz ve Bekmezci, 2012). Araştırmaya konu olan otel işletmeleri açısından gerçekleştirilmiş az sayıda 
çalışma olduğu gözlenmiştir. Akyüz ve Eşitti (2015) konaklama işletmeleri ve sağlık kurumlarına (hastaneler) yönelik yapılan çalışmada örgütsel bağııı̆ı̆ı alt boyutları (duygusal, devamlılık ve normatif bağlılık) ile işten ayrıma niyeti arasında negatif bir ilişki olduğu tespit edilmiştir. Zopiatis vd. (2014) Kıbrıs'ta otel işletme çalışanlarına yönelik yapılan çalışmada, duygusal ve normatif bağıllık ile işten ayrılma niyeti arasında negatif yönde ilişki olduğu sonucuna ulaşılmıştır. Arı (2014) dört ve beş yıldızlı otel çalışanlarına yönelik yaptığı çalışmada ise duygusal, devam ve normatif bağılı̆ğın işten ayrılma niyeti üzerinde etkisinin bulunmadığı görülmüştür. Yapılan çalışmalar, daha çok örgütsel bağlılığın işten ayrılma niyetini negatif yönde etkilediğidir. Dolayısıyla, otel işletmelerinde çalışanların örgüte bağııı̆̆ının, işten ayrılma niyetini negatif yönde etkileyeceği beklenmektedir. Buradan hareketle çalışmada aşağıdaki alternatif hipotez önerilmiştir:

H1c: Çalışanların örgütsel bağlılıklarının işten ayrılma niyeti üzerinde negatif etkisi vardır.

Yapılan çalışmalardan ve kavramsal çerçeveden, iş stresinin işten ayrılma niyetine etkisinde örgütsel bağı।ığın aracılık etkisinin bulunduğu düşünülerek aşağıda belirtilen araştırma hipotezi önerilmiş ve araştırma modeli Şekil-1'de sunulmuştur.

H1d: Çalışanların iş stresi ile işten ayrıma niyeti arasındaki ilişkide örgütsel bağlılığın aracılık etkisi vardır.

Şekil 1. Araştırmanın Modeli

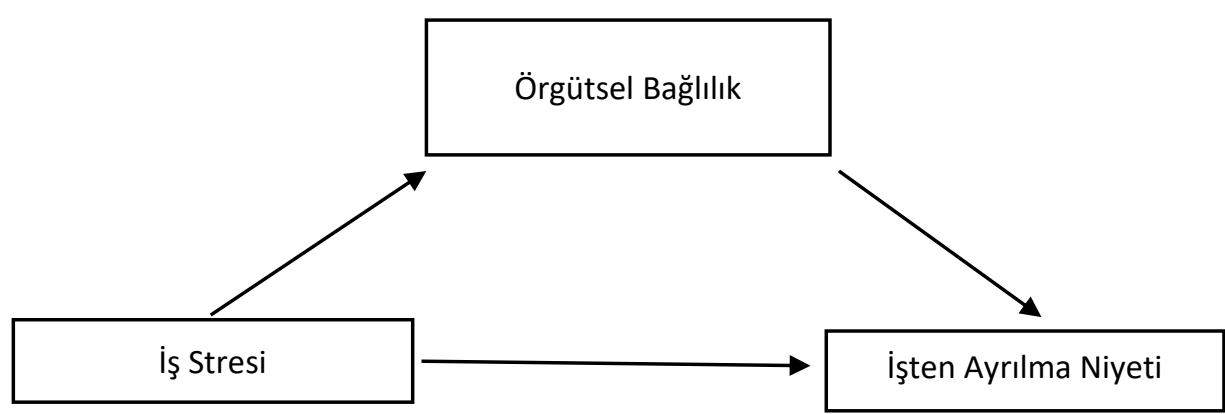

\section{Araştırmanın Yöntemi}

\subsection{Araştırmanın Ana Kütlesi ve Örneklemi}

Edirne'de T.C. Kültür ve Turizm Bakanlığı tarafından verilen Turizm İşletme Belgesi'ne sahip bir adet beş yıldızlı, bir adet dört yıldızlı, sekiz adet üç yıldızlı, dokuz adet iki yıldızlı, bir adet bir yıldızlı ve dört adet özel belgeye sahip toplam 24 adet otel işletmesi bulunmaktadır. Araştırmanın ana kütlesini bu 24 adet otel işletmesindeki tüm çalışanlar oluşturmaktadır. Ancak 24 otelden, 3 otelin kış mevsimi nedeniyle kapalı olması ve diğer 5 otele ulaşılamamış olması nedeniyle, araştırma 16 otel üzerinden gerçekleştirilmiştir. Ankete konu olan otel işletme yöneticilerinden alınan bilgilere göre, toplam 209 çalışan bulunmaktadır. Araştırmada kolayda örnekleme yöntemi kullanılmıştır. Bazı çalışanların anketi cevaplamak istememeleri nedeniyle 145 çalışan ile anket yapılmıştır. Çalışmanın örneklemi, ankete katılan 145 kişiden meydana gelmektedir. Dağııılan anketlerin geri dönüş oranı \%69,4'tür.

\subsection{Araştırmanın Veri Toplama Araçları ve Araştırmanın Analizi}

Araştırmada kullanılan veriler anket yöntemi ile elde edilmiştir. Anket formu iki bölümden oluşmaktadır. Birinci bölümde çalışanların "cinsiyet, yaş, eğitim durumu, çalıştığı departman ve çalışma süresi" gibi demografik özelliklerini ortaya koyacak sorular bulunmaktadır.

Anket formunun ikinci bölümünde 13 ifadeli beşli Likert soruları yer almaktadır (5-tamamen katılıyorum, 1-kesinlikle katılmıyorum). İkinci bölümde; çalışanların iş stresi, işten ayrılma niyeti ve örgütsel bağlılık düzeylerini tek boyutta ölçen üç ayrı ölçekten yararlanılmıştır. 
Yapılan anketler sonucunda elde edilen veriler SPSS 20.0 ve Amos 20 paket programları kullanılarak analiz edilmiştir. İlk olarak, önermelerin toplanacağı boyutu görebilmek için Keşfedici Faktör Analizi (KFA), ölçeğin güvenilirliğini değerlendirmek için Cronbach Alpha testi ve elde edilen verilerin daha önceden geliştirilmiş ve çeşitli araştırmalarda kullanılmış ölçeğin faktör yapısı ile uyumlu olup olmadığının tespit etmek için Doğrulayıcı Faktör Analizi (DFA) yapılmıştır. Daha sonra demografik soruların analizinde tanımlayıcı istatistikler kullanılmıştır. Üçüncü olarak değişkenler arası ilişkileri saptamak için korelasyon analizi, iş stresi ile işten ayrılma niyeti değişkenleri arasındaki ilişkide örgütsel bağlılığın aracılık etkisini tespit etmek için Baron ve Kenny (1986) tarafından önerilen dört aşamalı regresyon analizi yapılmıştır. Elde edilen istatistiksel bilgiler tablolar aracilığıyla ortaya konulmuştur.

İ̧ stresi ölçeği: Bu ölçek çalışanların iş stresi düzeylerini belirlemek için Cohen vd. (1983) tarafından geliştirilen ve Küçükusta (2007) tarafından Türkçeye çevrilip kullanılmış, 4 ifadeli bir ölçektir (Küçükusta, 2007).

Araştırmada iş stresi ölçeğinin yapısal geçerliliğini test etmek amacıyla KFA uygulanmıştır. Örneklemler analiz öncesinde, Kaiser-Meyer-Olkin (KMO) örneklem yeterlilik değeri ve Barlett küresellik testi ile ölçeğin faktör analizine uygunluğu araştırılmıştır. KMO değerinin 0,82 olduğu tespit edilmiş olup, bu değer örneklemin faktör analizi için yeterli olduğunu göstermektedir. Bartlett küresellik Testi sonucunun $p<0,000$ olarak tespit edilmiş olup, değişkenler arası ilişkilerin oluşturduğu matrisin faktör analizi için anlamlı olduğunu ve faktör analizi yapılabileceği anlamına gelmektedir. İş stresi ölçeğine ilişkin yapılan KFA sonucunda, verilerin tek faktörde toplandığı ve maddelerin faktör yüklerinin 0,85-0,93 arasında olduğu tespit edilmiştir. Elde edilen faktörlerle toplam varyansın \%78,41'nın açıklandığı ve ölçeğin yapısal geçerliliğini desteklediği görülmüştür (Tablo 1).

İş stresi ölçeğinin güvenilirliğinin (içsel tutarlılığının) değerlendirilmesinde Cronbach Alpha testi yapılmıştır. Araştırmada Cronbach Alpha güvenilirlik katsayısı 0,91 olarak bulunmuştur (Tablo 1). Bu sonuç, ölçeğin güvenilir olduğunu göstermektedir.

İşten ayrılma niyeti ölçeği: Bu ölçek çalışanların işten ayrılma niyetlerini ölçmek için Wayne vd. (1997) tarafından geliştirilmiş ve Küçükusta (2007) tarafından Türkçeye çevrilip kullanılmış üç ifadeli bir ölçektir (Küçükusta, 2007). Bu araştırmada ölçeğin yapısal geçerliliğini test etmek amacıyla KFA yapılmıştır. Analiz sonucunda KMO örneklem yeterliliği değeri 0,72 ve Bartlett küresellik Testi sonucunun $p<0,000$ olarak tespit edilmiştir. Çıkan bu sonuçlara göre veri seti faktör analizi yapmak için yeterince uygundur. KFA sonucunda üç madde tek faktörde toplandığı ve maddelerin faktör yüklerinin 0,89-0,95 arasında olduğu tespit edilmiştir. Elde edilen faktörlerle toplam varyansın $\% 84,75$ ni açıklandığı görülmüş ve ölçeğin yapısal geçerliliğini desteklediği tespit edilmiştir (Tablo 1 ).

İşten ayrılma niyeti ölçeğinin güvenilirliğinin (içsel tutarlılığının) değerlendirilmesinde yapılan Cronbach Alpha testi sonucunda, Cronbach Alpha güvenilirlik katsayısı 0,91 olarak bulunmuştur. Bu sonuç, ölçeğin güvenilir olduğunu göstermektedir (Tablo 1).

Örgütsel bağlııı ölçeği: Çalışanların örgütsel bağııık düzeylerini belirlemek için Jaworski ve Kohli (1993) tarafından geliştirilen ve Şeşen (2010) tarafından Türkçeye çevrilen ölçek kullanılmıştır. Bu ölçek, çalışanların genel olarak örgüte olan bağlılıklarını ölçmekte ve altı ifadeden oluşmaktadır (Şeşen, 2010).

Bu araştırmada örgütsel bağlıık ölçeğinin yapısal geçerliliğini test etmek amacıyla KFA uygulanmıştır. Ölçeğin faktör analizine uygunluğunu tespit etmek için KMO ve Barlett küresellik testi yapılmıştır. KMO örneklem yeterlilik değerinin 0,78 olduğu ve Bartlett küresellik Testi sonucunun $p<0,000$ olarak tespit edilmiştir. Çıkan bu sonuçlara göre veriler faktör analizi yapmak için yeterince uygundur. Örgütsel bağ|ıık ölçeğinin faktör analizi yapılması neticesinde 9 numaralı ifade 0,50 faktör yükü altında olması nedeniyle ölçekten çıkarılmıştır. KFA sonucunda verilerin tek faktörde toplandığı ve maddelerin faktör yüklerinin $0,75-$ 0,79 arasında olduğu tespit edilmiştir. Elde edilen faktörlerle toplam varyansın \%58,53'nü açıklandığı görülmüş ve ölçeğin yapısal geçerliliğini desteklediği tespit edilmiştir (Tablo 1). 
Örgütsel bağlılık ölçeğinin güvenilirliğinin değerlendirilmesi amacıyla yapılan Cronbach Alpha testi sonucunda, Cronbach Alpha güvenilirlik katsayısı 0,77 olarak bulunmuştur (Tablo 1). Bu sonuç, ölçeğin içsel tutarlıı̆ı̆ını yüksek ve güvenilir olduğunu göstermektedir.

Tablo 1. İş Stresi, İşten Ayrılma Niyeti ve Örgütsel Bağılıık Ölçeklerinin Faktör ve Güvenilirlik Analizi Sonuçları

\begin{tabular}{|c|c|c|c|c|c|}
\hline Ölçek & Sorular & $\begin{array}{l}\text { Faktör } \\
\text { Ağırlıkları }\end{array}$ & $\begin{array}{c}\text { Faktörün } \\
\text { Açıklayıcılığı (\%) }\end{array}$ & KMO & $\begin{array}{c}\text { Cronbach's } \\
\text { Alpha }\end{array}$ \\
\hline \multirow{4}{*}{ İ̧̧ Stresi } & Soru 13 & 0,93 & \multirow{4}{*}{78,41} & \multirow{4}{*}{0,82} & \multirow{4}{*}{0,91} \\
\hline & Soru 11 & 0,91 & & & \\
\hline & Soru 12 & 0,85 & & & \\
\hline & Soru 10 & 0,85 & & & \\
\hline \multirow{3}{*}{$\begin{array}{l}\text { İşten Ayrılma } \\
\text { Niyeti }\end{array}$} & Soru 15 & 0,95 & \multirow{3}{*}{84,75} & \multirow{3}{*}{0,72} & \multirow{3}{*}{0,91} \\
\hline & Soru 16 & 0,92 & & & \\
\hline & Soru 14 & 0,89 & & & \\
\hline \multirow{5}{*}{$\begin{array}{l}\text { Örgütsel } \\
\text { Bağlıık }\end{array}$} & Soru 6 & 0,79 & \multirow{5}{*}{58,53} & \multirow{5}{*}{0,78} & \multirow{5}{*}{0,77} \\
\hline & Soru 5 & 0,77 & & & \\
\hline & Soru 7 & 0,76 & & & \\
\hline & Soru 8 & 0,76 & & & \\
\hline & Soru 4 & 0,75 & & & \\
\hline
\end{tabular}

Araştırmada elde edilen verilerin, daha önceden geliştirilmiş ve daha önceki çalışmalarda kullanılmış ölçeğin faktör yapısı ile uyumlu olup olmadığının ortaya konulması için DFA uygulanmıştır. Doğrulayıcı faktör analizi sonuçları Tablo 2'de verilmiştir. İş stresi ölçeğine yapılan DFA sonucunda elde edilen uyum indekslerinin uyum kriterlerini sağladığı tespit edilmiştir $\left(\mathrm{X}^{2} / \mathrm{df}=2,053, \mathrm{RMSEA}=0,08, \mathrm{NFI}=0,99, \mathrm{CFI}=0,99\right.$, $\mathrm{GFI}=0,99, \mathrm{AGFI}=0,93)$. Buna göre, bu çalışma çerçevesinde iş stresi ölçeğinin tek faktörlü yapısı doğrulanmıştır (Tablo 2). Tablo 2'ye göre örgütsel bağlılık ölçeğine yapılan DFA sonucunda elde edilen uyum indekslerinin uyum kriterlerini sağladığı tespit edilmiştir $\left(X^{2} / d f=1,06, R M S E A=0,02, N F I=0,98, C F I=0,99, G F I=0,99\right.$, $A G F I=0,96)$. Buna göre, bu çalışma çerçevesinde örgütsel bağlılık ölçeğinin tek faktörlü yapısı doğrulanmıştır.

Tablo 2. Doğrulayıcı Faktör Analizi Sonuçları

\begin{tabular}{|l|c|c|c|c|c|c|}
\hline Ölçekler & $\mathbf{X}^{2} / \mathbf{d f}$ & RMSEA & NFI & CFI & GFI & AGFI \\
\hline i̇ş Stresi & 2,053 & 0,08 & 0,99 & 0,99 & 0,99 & 0,93 \\
\hline Örgütsel Bağlııık & 1,06 & 0,02 & 0,98 & 0,99 & 0,99 & 0,96 \\
\hline
\end{tabular}

\section{Araştırmanın Analizi ve Bulguları}

Araştırmaya katılan çalışanların demografik özelliklerine göre dağılımları Tablo 3'de verilmiştir. Tablodan da görüldüğü gibi, Araştırmaya katılan çalışanların \% 63,4'ü ( $n=92$ ) erkek ve \%36,6'sı ( $n=53$ ) kadındır. \%53,1'i (n=77) 20-30 yaş aralığında, \%24,8'i $(n=36) 31-40$ yaş aralı̆̆ında, \%17,2'si $(n=25) 41-50$ yaş aralığında ve \%4,8'i $(n=7) 51$ ve üzeri yaş aralığındadır. Çalışanların eğitim durumları; \% 37,9'u (n=55) lise, $\% 27,5^{\prime} i(n=40)$ lisansüstü, \%17,9'u ( $\left.n=26\right)$ ilköğretim ve \%16,6'sı $(n=24)$ ön lisans mezunudur. Ankete katılan 145 çalışanın görev pozisyonuna göre dağılımı \%29,7'si $(n=43)$ ön büro, $\% 26,2^{\prime}$ si $(n=38)$ restoran, \%24,1'i $(n=35)$ diğer görevler (kat hizmetleri, güvenlik), \%20,1'i ( $n=17)$ insan kaynakları, halkla ilişkiler, muhasebe, satış ve pazarlama bölümlerinde ve $\% 8,3^{\prime}$ ü $(n=12)$ mutfak görevlerinde çalışmaktadır. Ayrıca, ankete katılanların bu görev pozisyonlarında \%60'ı ( $n=87) 1$ ile 3 yıl arasında, \%26,2'si ( $n=38) 4$ ile 7 yıl arasında ve $\% 13,8^{\prime} i(n=20) 8$ yıldan fazla süredir çalışmakta oldukları tespit edilmiştir. 
İş Stresinin İşten Ayrılma Niyetine Etkisinde Örgütsel Bağlılığın Aracılık Rolü

Tablo 3. Ankete Katılan Çalışanların Demografik Özelliklerinin Dağıııı

\begin{tabular}{|c|c|c|c|c|c|c|c|}
\hline \multicolumn{2}{|c|}{ Değişken Adı } & \multirow{2}{*}{$\begin{array}{c}\text { Frekans } \\
53\end{array}$} & \multirow{2}{*}{$\begin{array}{c}\begin{array}{c}\text { Yüzde } \\
\text { (\%) }\end{array} \\
36,6 \\
\end{array}$} & \multicolumn{2}{|c|}{ Değişken Adı } & \multirow{2}{*}{$\begin{array}{c}\text { Frekans } \\
1 \\
\end{array}$} & \multirow{2}{*}{$\begin{array}{c}\begin{array}{c}\text { Yüzde } \\
\text { (\%) }\end{array} \\
0,7 \\
\end{array}$} \\
\hline & Kadın & & & \multirow{8}{*}{ Görev } & İnsan Kay. & & \\
\hline Cinsiyet & Erkek & 92 & 63,4 & & Halkla îliş. & 4 & 2,8 \\
\hline \multirow{4}{*}{ Yaş } & $20-30$ & 77 & 53,1 & & Ön büro & 43 & 29,7 \\
\hline & $31-40$ & 36 & 24,8 & & Muhasebe & 9 & 6,2 \\
\hline & $41-50$ & 25 & 17,2 & & Restoran & 38 & 26,2 \\
\hline & 51 ve üzeri & 7 & 4,8 & & Satış ve Paz. & 3 & 2,1 \\
\hline \multirow{5}{*}{$\begin{array}{l}\text { Eğitim } \\
\text { Durumu }\end{array}$} & İlköğretim & 26 & 17,9 & & Mutfak & 12 & 8,3 \\
\hline & Lise & 55 & 37,9 & & Diğer (...) & 35 & 24,1 \\
\hline & Ön Lisans & 24 & 16,6 & \multirow{3}{*}{$\begin{array}{l}\text { Görev } \\
\text { Süresi }\end{array}$} & $1-3$ yıl & 87 & 60,0 \\
\hline & Lisans & 35 & 24,1 & & $4-7 \mathrm{yll}$ & 38 & 26,2 \\
\hline & L. Üstü & 5 & 3,4 & & 8 yıl üzeri & 20 & 13,8 \\
\hline
\end{tabular}

Ankete katılan çalışanların örgütsel bağlılık, iş stresi ve işten ayrılma niyeti düzeyleri Tablo 4'de verilmiştir. Tabloya göre, çalışanların örgütsel bağıılık düzeyi ortalamanın üzerinde değer aldığı görülmektedir. Buna göre, çalışanların örgütlerine bağlı oldukları söylenebilir. Diğer taraftan iş stresi ve işten ayrılma niyeti düzeylerinin ise ortalamanın altında olduğu tespit edilmiştir. Bu durum, çalışanların iş streslerinin ve işten ayrılma niyetlerinin düşük olduğunu göstermektedir.

Tablo 4. Değişkenler Arasındaki Korelasyon Analizi Sonuçları

\begin{tabular}{|l|r|r|r|r|c|}
\hline Değişkenler & Ortalama & $\begin{array}{c}\text { Standart } \\
\text { Sapma }\end{array}$ & $\mathbf{1}$ & $\mathbf{2}$ & $\mathbf{3}$ \\
\hline İş Stresi & 1,90 & 0,773 & - & - & - \\
\hline Örgütsel Bağlılık & 4,07 & 1,112 & $-0,403\left(^{* *}\right)$ & - & - \\
\hline İşten Ayrılma Niyeti & 1,75 & 1,100 & $0,515\left(^{* *}\right)$ & $-0,657\left(^{* *}\right)$ & - \\
\hline
\end{tabular}

**Korelasyon 0,01 düzeyinde anlamlı (iki yönlü).

Çalışanların iş stresi, örgütsel bağlılık ve işten ayrılma niyetleri arasındaki ilişki korelasyon analizi ile araştırılmıştır. Analiz sonuçları Tablo 4'de verilmiştir. Tablodan da görüldüğü gibi, iş stresi ile örgütsel bağıııı arasında negatif yönde anlamlı bir ilişki $(r=-0,403, p<0,000)$ ve örgütsel bağlılık ile işten ayrılma niyeti arasında negatif yönde anlamlı bir ilişki $(r=-0,657, p<0,000)$ olduğu tespit edilmiştir. İ̧̧ stresi ile işten ayrılma niyeti arasında ise pozitif yönde anlamlı bir ilişki $(r=0,515, p<0,000)$ olduğu sonucuna ulaşılmıştır.

İ̧ stresi ile işten ayrılma niyeti arasındaki ilişkide örgütsel bağlıı̆ın aracılık rolünü belirlemek için Baron ve Kenny'nin (1986) önerdiği dört aşamalı test sonuçları Tablo 5'de verilmiştir. Birinci aşamada iş stresinin işten ayrılma niyeti üzerinde pozitif yönlü ve anlamlı etkisinin $(\beta=0,515, p<0,000)$ olduğu bulunmuş olup, işten ayrılma niyetinin \%51,5'nin iş stresi tarafından açıklandığı gözlenmiştir ( $F=55,587, R^{2}=0,265$, Sig. $=$ $0,000)$. Bu durumda, H1a hipotezi kabul edilmiştir. İkinci aşamada iş stresinin örgütsel bağlılık üzerinde negatif yönlü ve anlamlı etkisinin $(\beta=-0,403, p<0,000)$ olduğu tespit edilmiş olup, örgütsel bağlılığın $\% 40,3^{\prime}$ nün iş stresi tarafından açıklandığı sonucuna ulaşılmıştır $\left(F=29,793, R^{2}=0,162\right.$, Sig.= 0,000). Bu durumda, H1b hipotezi kabul edilmiştir. Üçüncü aşamada örgütsel bağlılığın işten ayrılma niyeti üzerinde negatif yönlü ve anlamlı etkisi $(\beta=-0,657, p<0,000)$ olduğu tespit edilmiş olup, işten ayrılma niyetinin $\% 65,7$ 'si örgütsel bağlılık tarafından açıklandığı sonucuna ulaşımıştır $\left(F=116,786, R^{2}=0,431\right.$, Sig. $\left.=0,000\right)$. Bu durumda, $\mathrm{H} 1 \mathrm{c}$ hipotezi kabul edilmiştir. 
Tablo 5. Regresyon Analizi Sonuçları

\begin{tabular}{|c|c|c|c|c|c|c|c|c|c|}
\hline \multirow{2}{*}{ Model } & \multirow{2}{*}{$\begin{array}{l}\text { Bağımsız } \\
\text { Değişkenler }\end{array}$} & \multirow{2}{*}{$\begin{array}{l}\text { Bağımlı } \\
\text { Değ. }\end{array}$} & \multicolumn{5}{|c|}{ Regresyon Katsayıları } & \multicolumn{2}{|c|}{$\begin{array}{c}\text { Model } \\
\text { İstatistikleri }\end{array}$} \\
\hline & & & B & $\begin{array}{l}\text { Std. } \\
\text { Hata }\end{array}$ & $\beta$ & $\mathbf{t}$ & p & $\mathbf{R}^{2}$ & $\mathbf{F}$ \\
\hline \multirow[b]{2}{*}{$\begin{array}{l}\text { Birinci } \\
\text { Aşama }\end{array}$} & Sabit & & 0,776 & 0,150 & & 5,16 & 0,000 & \multirow[b]{2}{*}{0,265} & \multirow[b]{2}{*}{55,587} \\
\hline & İş Stresi & $\begin{array}{l}\text { İşten } \\
\text { Ayrılma } \\
\text { Niyeti }\end{array}$ & 0,509 & 0,068 & 0,515 & 7,46 & 0,000 & & \\
\hline \multirow[b]{2}{*}{$\begin{array}{l}\text { İkinci } \\
\text { Aşama }\end{array}$} & Sabit & & 4,600 & 0,113 & & 40,74 & 0,000 & \multirow[b]{2}{*}{0,162} & \multirow[b]{2}{*}{29,793} \\
\hline & İş Stresi & $\begin{array}{l}\text { Örgütsel } \\
\text { Bağ|ılık }\end{array}$ & $-0,280$ & 0,051 & $-0,403$ & $-5,458$ & 0,000 & & \\
\hline \multirow[b]{2}{*}{$\begin{array}{l}\text { Üçüncü } \\
\text { Aşama }\end{array}$} & Sabit & & 5,547 & 0,358 & & 15,50 & 0,000 & \multirow[b]{2}{*}{0,431} & \multirow[b]{2}{*}{116,786} \\
\hline & Örgütsel Bağlılık & $\begin{array}{l}\text { İşten } \\
\text { Ayrılma } \\
\text { Niyeti }\end{array}$ & $-0,935$ & 0,086 & $-0,657$ & $-10,81$ & 0,000 & & \\
\hline \multirow{3}{*}{$\begin{array}{l}\text { Dördüncü } \\
\text { Aşama }\end{array}$} & Sabit & & 4,287 & 0,425 & & 10,09 & 0,000 & \multirow{3}{*}{0,506} & \multirow{3}{*}{78,430} \\
\hline & İş Stresi & İşten & 0,296 & 0,061 & 0,299 & 4,82 & 0,000 & & \\
\hline & $\begin{array}{l}\text { Örgütsel Bağlılık } \\
\text { (Aracı Değiş) }\end{array}$ & $\begin{array}{l}\text { Ayrilma } \\
\text { Niyeti }\end{array}$ & $-0,763$ & 0,088 & $-0,536$ & $-8,64$ & 0,000 & & \\
\hline
\end{tabular}

Dördüncü aşamada aracı değişken analize dahil edilmiştir. İş stresinin işten ayrılma niyeti üzerindeki etkisi birinci aşamada $\beta=0,515(p<0,000)$ değerinde iken, aracı değişken olan örgütsel bağılığın modele dâhil edilmesiyle iş stresinin işten ayrılma niyeti üzerindeki etkisi dördüncü aşamada $\beta=0,299(p<0,000)$ değerine düşmüştür. Çıkan bu sonuçlar, iş stresinin işten ayrılma niyetine etkisinde örgütsel bağlıığın aracılık etkisinin olduğunu göstermektedir. Ancak bu etki kısmi bir etkidir. Ayrıca, Sobel testinin hesaplanması sonucunda, aracılık etkisinin istatistiksel olarak anlamlı $(Z=4,901 ; p=0,000)$ olduğu tespit edilmiştir. Böylece araştırmanın H1d hipotezinin kısmen kabul edildiği söylenebilir.

\section{Sonuç ve Öneriler}

Emeğin yoğun olduğu bir endüstri içerisinde faaliyet gösteren otel işletmelerindeki çalışanlar, müşterilere kaliteli hizmetin verilmesinde ve müşteri memnuniyetinin sağlanabilmesinde önemli bir rol oynamaktadırlar. Memnun olmuş bir müşterinin tekrar otel işletmesini tercih etmesi işletmenin başarısı açısından oldukça önemlidir. Ancak, çalışanların gelen misafirlerle yüz yüze iletişimde bulunmaları, hizmet sunumunu eş zamanlı olarak gerçekleştirmeleri, uzun saatler çalışmak zorunda olmaları, terfi olanaklarının yetersizliği, düşük maaşla çalışmaları, onların aşırı strese maruz kalmalarına neden olabilmektedir (Akova vd., 2015). Aşırı strese maruz kalan otel çalışanlarında işine ve iş yerine olan bağlılıklarında azalma, işten ayrılma niyetlerinde ise artma yaşanabilmektedir. Otel çalışanlarının işten ayrılma niyetlerinin fazlalığı, çalışanlarda niyetin davranışa dönüşmesi sonucunu ortaya çıkartabilmektedir (Turunç ve $A v c ı, 2015)$. Bu durum, işletmeler açısından maliyetlerin artması, çalışanlar açısından yeni bir iş bulma zorluğu gibi olumsuz bir takım sonuçlara neden olabilmektedir.

Araştırma sonuçlarına göre, ankete katılan çalışanların iş stresi ve işten ayrılma niyeti düşük düzeyde çıkmıştır. Bu durum ankete katılan çalışanların iş ortamında yaşadıkları stresin düşük olduğu ve işten ayrılmayı düşünmedikleri söylenebilir. Diğer taraftan, katılımcıların örgütsel bağlılık düzeylerinin, ortalama değerden yüksek olduğu sonucuna ulaşılmıştır. Bu durum, çalışanlar tarafından işletmenin sağladığı olanakların ve çalışma koşullarının tatmin edici bulunmasından kaynaklanabilir. Bu çalışmayı destekleyen başka bir çalışmada (Sökmen ve Şimşek, 2016) da çalışanların örgütsel bağlılıkları yüksek, iş stresi ve işten ayrılma niyetleri düşük olarak gerçekleşmiştir. Tekingündüz ve Kurtuldu (2015), Kahramanmaraş ilinde bir kamu hastanesindeki çalışanlara yönelik yaptıkları çalışmada işten ayrılma niyeti düzeyleri ortalamanın altında gerçekleşirken, örgütsel bağlılık ve iş stresi düzeyleri orta düzeyde gerçekleşmiştir (Tekingündüz ve Kurtuldu, 2015). Başka bir çalışmaya göre ise, örgütsel bağlılık, iş stresi ve işten ayrılma niyetleri orta düzeyde gerçekleşmiştir (Zincirkıran vd., 2015). 
Araştırmada yapılan korelasyon analizinde, iş stresi ile örgütsel bağlılık arasında negatif yönde anlamlı bir ilişki olduğu sonucuna ulaşılmıştır. Buna göre, çalışanların iş stresi düzeyi azaldıkça örgütsel bağılık düzeyinin artacağı söylenebilir. Çıkan bu sonuç, daha önce yapılmış çalışmalarla (Atay, 2012; Rizvi ve Rana, 2012; Türker, 2013; Bhatti vd., 2016; Sökmen ve Şimşek, 2016) da tutarlılık göstermektedir. Diğer taraftan başka bir çalışmada, iş stresi ile örgütsel bağılık arasında pozitif bir ilişki bulunurken (Mojtabazadeh, Miarkolaei ve Miarkolaei, 2016: 8), başka bir çalışmada ise, iş stresi ile örgütsel bağlılık arasında herhangi bir ilişki bulunamamıştır (Gül vd., 2008).

Diğer bir korelasyon analizi sonucuna göre, iş stresi ile işten ayrılma niyeti arasında pozitif yönde anlamlı bir ilişki bulunmuştur. Bu çalışmayı destekleyen başka çalışmalarda (Arshadi ve Damiri, 2013; Türker, 2013; Yenihan vd., 2014; Tekingündüz ve Kurtuldu, 2015; Saltık, 2016) da iş stresi ile işten ayrılma niyeti arasında pozitif yönde anlamlı bir ilişki bulunmaktadır. Buna göre, çalışanın stres düzeyi arttıkça, işten ayrılma niyeti artacak hatta işten bile ayrılabileceklerdir. Bu durumda, işletmelerin çalışanlarının stres düzeylerini azaltacak önlemler alması gerekmektedir.

Araştırma sonucuna göre, örgütsel bağlılık ile işten ayrılma niyeti arasında negatif yönde anlamlı bir ilişki olduğu tespit edilmiştir. Buna göre, çalışanların işletmeye olan bağlılık düzeyleri arttıkça işten ayrılma niyetleri azalacaktır. Literatürde bu çalışmayı destekleyen başka çalışmalarda (Çakar ve Ceylan, 2005; Gül vd., 2008; Türker, 2013; Sökmen ve Şimşek, 2016) bulunmaktadır.

Yapılan bu çalışmada, Baron ve Kenny'nin (1986) önerdiği dört aşamalı regresyon analizi kullanılarak, iş stresinin işten ayrılma niyeti üzerindeki etkisinde örgütsel bağlıığın aracılık rolü incelenmiştir.

Regresyon analizinin ilk aşamasında, iş stresinin işten ayrılma niyeti üzerinde pozitif yönlü ve anlamlı bir etkisinin olduğu belirlenmiştir. Buna göre, otel işletmelerinde artan iş stresi çalışanların işten ayrılma niyetini artıracaktır. Literatürde otel işletme çalışanlarına yönelik yapılmış çalışmalar (Onay ve Kılıcı, 2011; Akova vd., 2015; Gök vd., 2017) da bu çalışmayı desteklemektedir. Bunun yanında farklı sektörlerde yapılan araştırmalarda (Noor ve Maad, 2008; Arshadi ve Damiri, 2013; Qureshi vd., 2013; Türker, 2013; Iqbal vd., 2014; Yenihan vd. 2014; Tekingündüz ve Kurtuldu 2015; Savaş ve Erol, 2017) da iş stresinin işten ayrılma niyetini pozitif yönde etkilediği tespit edilmiştir. Otel işletme çalışanlarına yönelik yapılan başka çalışmaya (Saltık, 2016) göre ise, iş stresinin işten ayrılma niyeti üzerinde herhangi bir anlamlı etkisinin olmadığı tespit edilmiştir. Diğer bir deyişle, stres düzeyinde meydana gelen artı̧ veya azalış çalışanları işten ayrılmaya itmemiştir (Saltık, 2016).

Araştırmanın ikinci aşamasında iş stresinin örgütsel bağlılık üzerinde negatif yönlü ve anlamlı etkisinin olduğu tespit edilmiştir. Buna göre, işletmede iş stresinin azalması örgütsel bağlılığın artmasına neden olabilecektir. Daha önce yapılan başka çalışmalar (Sökmen ve Şimşek, 2006; Lambert ve Paoline, 2008; Uzun ve Yiğit, 2011; Atay, 2012; Nazım ve Kakakhel, 2013; Garg ve Dhar, 2014; Alipour ve Monfared, 2015; Tekingündüz vd., 2015; Akpulat vd., 2016; Bhatti vd., 2016) da bu çalışmayı desteklemektedir.

Araştırmanın üçüncü aşamasında, örgütsel bağlılık işten ayrılma niyetini negatif yönde ve anlamlı olarak etkilemektedir. Daha önce yapılan çalışmalarda (Sökmen ve Şimşek, 2006; Gül vd., 2008; Akyüz ve Eşitti, 2015; Tekingündüz ve Kurtuldu, 2015) da örgütsel bağlıı̆̆ın işten ayrılma niyetini negatif yönde ve anlamlı olarak etkilediği ifade edilmektedir. Buna göre, bir iş yerinde çalışan bireyin işine ve iş yerine olan bağııı̆̆ının artması, o çalışanın işten ayrılma düşüncesi de o oranda azalabilir ya da ortadan kalkabilir.

Araştırmanın son aşamasında, iş stresinin işten ayrılma niyeti üzerindeki etkisinde örgütsel bağlılı̆ın aracılık rolü incelenmiştir. Elde edilen sonuçlara göre, iş stresinin işten ayrılma niyeti üzerindeki etkisinde örgütsel bağıılığın kısmi aracılık rolü olduğu sonucuna ulaşılmıştır. Çalışanların iş stresleri azaldıkça örgüte olan bağlılıkları artmakta ve bu da çalışanların işten ayrılma niyetini azaltmaktadır. Dolayısıyla, iş stresinin işten ayrılma niyetine etkisini araştırmak üzere yapılacak başka çalışmalarda da örgütsel bağlılı̆ın aracılık rolü göz önüne alınmalıdır.

Ayrıca, işletme sahipleri ve yöneticilerinin çıkan bu sonucu göz önüne alarak uygun iş koşullarının ve örgüt yapısının oluşturulması yönünde çaba harcamaları, çalışanların örgütsel bağlılıklarını artırmaları ve iş yerinde yaşanacak olumsuz stres unsurlarının (düşük ücretlerin ve terfi olanaklarının iyileştirilmesi, aşırı iş 
yükünün azaltılması vb.) ortadan kaldırılması için faaliyetlerde bulunmaları gerekmektedir. Böylece bir yandan çalışanların performansı ve verimliliği artarken, diğer yanda işten ayrılma niyetleri de azalacaktır.

Literatür incelemesinde iş stresi, örgütsel bağlılık ve işten ayrılma niyeti değişkenlerinin ikili olarak ilişkilerini inceleyen çok sayıda araştırma bulunmaktadır. Ancak, yapılan çalışmalarda iş stresinin işten ayrılma niyetine etkisinde örgütsel bağlıığın aracılık etkisini inceleyen çalışmaya rastlanmamıştır. Çalışmanın, bu yönüyle ilgili literatüre katkı sağlayacağı düşünülmektedir. Bu çalışmanın bazı kısıtları bulunmaktadır: Illk kısıtı araştırmanın örneklemi sadece Edirne ilindeki otel işletme çalışanlarından oluşması ve araştırmaya sınırlı sayıda ( $\mathrm{N}=145)$ çalışanın katılması genellenebilirlik açısından bir kısıttır. Diğer bir kısıtı ise, ankete katılanlar vermiş oldukları cevapların işverenlerinin ya da yöneticilerinin eline geçme ihtimaline karşı içinde bulundukları durumu tam olarak yansıtmamış olabilirler. Üçüncü kısıtı katılımcıların o anki ruh hali ve içinde bulundukları duruma göre bir değerlendirme yapmış olmalarıdır.

Ileride yapılacak çalışmalarda sadece Turizm Işletme Belgesi'ne sahip olan otel işletmeleri değil, ayrıca belediyelere bağlı otel işletmeleri de araştırma kapsamına alınabilir. Bunun yanında çalışma alanı genişletilerek Tekirdağ, Kırklareli ve Edirne illerinde faaliyet gösteren otel işletmeleri de araştırma kapsamına dahil edilebilir. Ayrıca, değişkenler (iş stresi, işten ayrılma niyeti ve örgütsel bağlılık) ile örgütsel sessizlik, sinizim, personel güçlendirme, performans gibi değişkenler arasındaki ilişkiler incelenebilir.

\section{Kaynaklar}

Akova, O., Emiroğlu, B. D., \& Tanrıverdi, H. (2015). İ̧̧ stresi ile çalışanların iş tatmini ve işten ayrılma niyeti arasındaki iliş̧i: İstanbul'daki 5 yıldızlı otel işletmelerinde bir araştırma. Journal of Management, Marketing and Logistics, 2(4), 378-402.

Akpulat, A. N., Üzümcü, P. T., \& Karacan, E. (2016). Turizm işletmelerinde çalışanların yaşadıkları iş stresi ile örgütsel bağlı।ıkları ilişkisi, Çeşme ve Karatepe örneği. Journal of Human Sciences, 13(3), 5136-5149.

Akyüz, B., \& Eşitti, B. (2015). Hizmet işletmelerinde örgütsel bağlılığın iş performansı ve işten ayrılma niyeti üzerindeki etkisi: Çanakkale örnekleminde bir araştırma. Bartın Üniversitesi i.i. B.F.Dergisi, 6(11), 23-39.

Alipour, F., \& Monfared, K. M. (2015). Examining the relationship between job stress and organizational commitment among nurses of hospitals. Patient Saf Qual Improv, 3(4), 277-280.

Allen, N. J., \& Meyer, J. P. (1990). The measurement and antecedents of affective, continuance and normative commitment to the organization. Journal of Occupational Psychology, 63, 1-18.

Arı, G. (2014). Örgütsel bağlılık, örgütsel vatandaşıık davranışı ve işten ayrılma niyeti arasındaki ilişki: 4 ve 5 yıldızlı otel uygulaması. Adnan Menderes Üniversitesi Sosyal Bilimler Enstitüsü, Basılmamış Yüksek Lisans Tezi, Aydın.

Arshadi, N., \& Damiri, H. (2013). The relationship of job stress with turnover intention and job performance: Moderating role of OBSE. Procedia - Social and Behavioral Sciences, 84, 706-710.

Atay, Ö. (2012). Çalışma yaşamında stres ve örgütsel bağılıı̆a etkisi. Uludağ Üniversitesi Sosyal Bilimler Enstitüsü, Basılmamış Yüksek Lisans Tezi, Bursa.

Baron, R., M., \& Kenny, A. D. (1986). The moderator-mediator variable distinction in social psychological research: Conceptual, strategic and statistical considerations. Journal of Personality and Social Psychology, 6(511), 11731182.

Bhatti, M. H., Bhatti, M. H., Akram, M. U., Zubair, M., H., \& Akram, Z. (2016). Relationship between job stress and organizational commitment: An empirical study of banking sector. Journal of Business Management and Economics, 7(1), 29-37.

Bozkurt, Ö., \& Yurt, ì. (2013). Akademisyenlerin örgütsel bağlıık düzeylerini belirlemeye yönelik bir araştırma. Yönetim Bilimleri Dergisi, 11(22), 121-139.

Büyükbeşe, T. (2011). Stres ve stres yönetimi. Ed. İsmail Bakan, Çağdaş Yönetim Yaklaşımı (ss.36-57), İstanbul: Beta Yayınevi.

Cotton, J. L., \& Tuttle, J. M. (1986). Employee turnover: A meta-analysis and review with implications for research. The Academy of Management Review, 11(1), 55-70.

Çakar, N. D., \& Ceylan, A. (2005). İş motivasyonunun çalışan bağlılığı ve işten ayrılma eğilimi üzerindeki etkileri. Doğuş Üniversitesi Dergisi, 6(1), 52-66. 
Çekmecelioğlu, H. G., \& Pelenk, S. E. (2015). Örgütsel engellerin, örgütsel bağlılık ve iş performansı üzerindeki etkileri: Kocaeli lastik işletmelerinde bir araştırma. Kocaeli Üniversitesi Sosyal Bilimler Dergisi, 29, 143-164.

Çiftçi, Ö. D., Meriç, E., \& Meriç, A. (2015). Örgütsel sessizlik, tükenmişlik ve işten ayrılma niyeti ilişkisi: Ordu ili özel eğitim ve rehabilitasyon merkezlerinde bir uygulama. Uluslararası Sosyal Araştırmalar Dergisi, 8(41), 996-1007.

Demir, C., \& Öztürk, U. C. (2011). Örgüt kültürünün örgütsel bağlılık üzerine etkisi ve bir uygulama. Dokuz Eylül Üniversitesi Iktisadi ve Idari Bilimler Fakültesi Dergisi, 26(1), 17-41.

Doğan, S., \& Kılıç, S. (2007). Örgütsel bağlılığın sağlanmasında personel güçlendirmenin yeri ve önemi. Erciyes Üniversitesi Iktisadi ve Idari Bilimler Fakültesi Dergisi, 29, 37-61.

Düzgün, A. (2014). Üst düzey yöneticilerde örgütsel stres ve örgütsel bağlılık ilişkisi analizi: Antalya bölgesi beş yıldızlı otel işletmelerinde bir uygulama. Adnan Menderes Üniversitesi Sosyal Bilimler Enstitüsü, Basılmamış Yüksek Lisans Tezi, Aydın.

Efeoğlu, İ. E., \& Özgen, H. (2007). İş-aile yaşam çatışmasının iş stresi, iş doyumu ve örgütsel bağılık üzerindeki etkileri: İlaç sektöründe bir araştırma. Ç.Ü. Sosyal Bilimler Enstitüsü Dergisi, 16(2), 237-254.

Emhan, A., Kula, S., \& Töngür, A. (2013). Yapısal eşitlik modeli kullanılarak yönetici desteği, örgütsel bağlılık, örgütsel performans ve tükenmişlik kavramları arasındaki ilişkilerin analizi: Kamu sektöründe bir uygulama. Hacettepe Üniversitesi İktisadi ve Idari Bilimler Fakültesi Dergisi, 31(1), 53-69.

Garg, S., \& Dhar, L. R. (2014). Effects of stress, Imx and perceived organizational support on service quality: Mediating effects of organizational commitment. Journal of Hospitality and Tourism Management, 21, 64-75.

Gök, A. Ö., Akgündüz, Y., \& Alkan, C. (2017). The effects of job stress and perceived organizational support on turnover intentions of hotel employees. Journal of Tourismology, 3(2), 23-32.

Gül, H., Oktay, E., \& Gökçe, H. (2008). İş tatmini, stres, örgütsel bağlılık, işten ayrılma niyeti ve performans arasındaki ilişkiler: Sağlık sektöründe bir uygulama. Akademik Bakış Sosyal Bilimler Dergisi, (0)15, 1-11.

Gürbüz, S., \& Bekmezci, M. (2012). İnsan kaynakları yönetimi uygulamalarının bilgi iş̧̧ilerinin işten ayrılma niyetine etkisinde duygusal bağııı̆ı̆ aracılık ve düzenleyicilik rolü. İstanbul Üniversitesi İşletme Fakültesi Dergisi, 41(2), 189-213.

Gürel, B. E. (2016). Duygusal tükenmişlik, iş stresi ve işe bağıılığın iş-aile çatışması üzerindeki etkisi: Amprik bir araştırma. Sosyal Bilimler Dergisi, 48, 349-364.

Karahan, A. (2009). Hekimlerin örgütsel bağlılık ve iş tatmini ilişkisinin incelenmesine yönelik bir araştırma: Afyon Kocatepe Üniversitesi örneği. Dumlupınar Üniversitesi, Sosyal Bilimler Dergisi, 0(23), 421-432.

Karavardar, G. (2015). Örgütsel adaletin iş tatmini, örgütsel bağlılık ve işten ayrılma niyeti üzerindeki etkisi. Uluslararası Yönetim iktisat ve işletme Dergisi, 11(26), 139-150.

Kerse, G. (2016). Motivasyon araçlarının örgütsel bağlılık üzerindeki etkisi: kamu kurumlarındaki $X$ ve $Y$ kuşağı karşılaştırması. Business \& Management Studies: An International Journal, 4(1), 1-23.

Kılıç, G., Tunç, T., Saraçlı, S., \& Kılıç, İ. (2013). Örgütsel stresin örgütsel sessizlik üzerine etkisi: Beş yıldızlı termal otel işletmelerinde bir uygulama. Işletme Araştırma Dergisi, 5(1), 17-32.

Küçükusta, D. (2007). Konaklama işletmelerinde iş-yaşam dengesinin çalışma yaşamı kalitesi üzerindeki etkisi. Dokuz Eylül Üniversitesi Sosyal Bilimler Enstitüsü, Yayımlanmamış Doktora Tezi, Bursa.

Lambert, G. E., \& Paoline, A. E. (2008). The influence of individual, job and organizational characteristics on correctional staff job stress, job satisfaction and organizational commitment. Criminal Justice Review, 33(4), 541-564.

Lambert, E., \& Hogan, N. (2009). The importance of job satisfaction and organizational commitment in shaping turnover Intent a test of a causal model. Criminal Justice Review, 34(1), 96-118.

Iqbal, S., Ehsan, S., Rizwan, M., \& Noreen, M. (2014). The impact of organizational commitment, job satisfaction, job stress and leadership support on turnover intention in educational institutes. International Journal of Human Resource Studies, 4(2), 181-195.

Mojtabazadeh, H., Miarkolaei, H. S., \& Miarkolaei, H. S. (2016). The relationship between job stress and organizational commitment in tax organization. Journal of Industrial Strategic Management, 1(2), 1-14.

Nazım A., \& Kakakhel, J. S. (2013). Relationship between occupational stress and organizational commitment (empirical evidence from pharmaceuticals industry). Journal of Managerial Science, 7(2), 291-298.

Noor, S., \& Maad, N. (2008). Examining the relationship between work life conflict, stress and turnover intentions among marketing executives in Pakistan. International Journal of Business and Management, 3(11), 93-102. 
Onay, M., \& Kılıcı, S. (2011). İş stresi ve tükenmişlik duygusunun işten ayrılma niyeti üzerine etkileri: Garsonlar ve aşçıbaşılar. Organizasyon Ve Yönetim Bilimleri Dergisi, 3(2), 363-372

Pham, L., \& Pham, L. (2016). The effects of job satısfaction and organizatıonal commitment on intention to stay: Case study at the universities, colleges in Bac Lieu City, Bac Lieu Province. The 10th International Days of Statistics and Economics, 8(10), 14451459.

Qureshi, I. M., Iftikhar, M., Abbas, G. S., Hassan, U., Khan, K., \& Zaman, K. (2013). Relationship between job stress, workload, environment and employees turnover intentions: What we know, what should we know. World Applied Sciences Journal, 23(6), 764- 770.

Rizvi, S. N. Z., \& Rana, A. S., (2012). Effectiveness of corporate social responsibility in controlling the impact of job stress on organizational commitment: A study of banking sector of Pakistan. Interdisciplinary Journal Of Contemporary Research in Business Copy Right, 4(8), 321-332.

Rusbult, C. E., \& Farrell, D. (1983). A longitudinal test of the investment model: The impact on job satisfaction, job commitment, and turnover of variations in rewards, costs, alternatives, and investments. Journal of Applied Psychology, 68(3), 429-438.

Saltık, Z. (2016). Stresin iş gören performansına ve işten ayrılma niyetine etkisi: Konaklama işletmelerinde bir uygulama. Nevşehir Hacı Bektaş Veli Üniversitesi Sosyal Bilimler Enstitüsü, Yayımlanmamış Yüksek Lisans Tezi, Nevşehir.

Savaş, C. A., \& Erol, F. (2017). Eğitim personellerinde iş stresinin işten ayrılma niyetine etkisinde depresyon düzeylerinin aracılık etkisi. Yaşam Becerileri Psikoloji Dergisi, 1(2), 115-123.

Seyrek, i. H., \& Inal, O. (2017). İşten ayrılma niyeti ile ilişkili faktörler: Bilgi teknolojisi çalışanları üzerine bir araştırma. Doğu Anadolu Sosyal Bilimlerde Eğilimler Dergisi, 1(1) 63-74.

Sökmen, A., \& Şimşek, T. (2016). Örgütsel bağlılık, örgütle özdeşleşme, stres ve işten ayrılma niyeti ilişkisi: Bir kamu kurumunda araştırma. Gazi Üniversitesi Iktisadi ve Idari Bilimler Fakültesi Dergisi, 18(3), 606-620.

Şahin, B. (2014). Seyahat acentası çalışanlarında örgütsel stresin örgütsel bağlılıkla ilişkisi üzerine bir araştırma: İstanbul örneği. Balıkesir Üniversitesi Sosyal Bilimler Dergisi, 17(32),193-210.

Şeşen, H. (2010). Öncülleri ve sonuçları ile örgüt içi girişimcilik: Türk savunma sanayinde bir araştırma. Kara Harp Okulu Savunma Bilimleri Enstitüsü Savunma, Yayımlanmamış Doktora Tezi, Ankara.

Tekingündüz, S., \& Kurtuldu, A. (2015). İşten ayrılma niyeti, iş tatmini, örgütsel bağlılık, liderlik ve iş stresi arasındaki ilişkilerin analizi: Bir hastane örneği. International Journal of Human Sciences, 12(1), 1501-1517.

Tekingündüz, S., Top, M., \& Seçkin, M. (2015). İş tatmini, performans, iş stresi ve işten ayrılma niyeti arasındaki ilişkilerin incelenmesi: Hastane örneği. Verimlilik Dergisi, 0(4), 39-64.

Turunç, Ö., \& Çelik, M. (2010). Çalışanların algıladıkları örgütsel destek ve iş stresinin örgütsel özdeşleşme ve iş performansına etkisi. Yönetim ve Ekonomi Dergisi, 17(2), 183-206.

Turunç, Ö., \& Avcı, U. (2015). Algılanan örgütsel destek ve lider-üye etkileşiminin işten ayrılma niyeti üzerindeki etkisi: İş stresinin aracılık rolü. Seyahat ve Otel Işsletmeciliği Dergisi, 12(1), 43-63.

Türker, N. E. (2013). Bankacılık sektöründe çalışanların stres düzeyi ile işten ayrılma niyeti arasındaki ilişkinin örgüte bağlılık üzerine etkisi. Marmara Üniversitesi Bankacılık ve Sigortacılık Enstitüsü, Yayımlanmamış Doktora Tezi, İstanbul.

Uzun, Ö., \& Yiğit, E. (2011). Örgütsel stres ve örgütsel bağlılık ilişkisi üzerine orta kademe otel yöneticileri üzerinde yapılan bir araştırma. Eskişehir Osmangazi Üniversitesi iiBF Dergisi, 6(1), 181-213.

Yalçın, A., \& İplik, N. F. (2005). Beş Yıldızlı otellerde çalışanların demografik özellikleri ile örgütsel bağlılıkları arasındaki ilişkiyi belirlemeye yönelik bir araştırma: Adana ili örneği. Çukurova Üniversitesi Sosyal Bilimler Enstitüsü Dergisi, 4(1), 395-412.

Yenihan, B., Öner, M., \& Çiftyıldız, K. (2014). İş stresi ve işten ayrılma niyeti arasındaki ilişki: Otomotiv işletmesinde bir araştırma. Çalışma iliş̧kileri Dergisi, 5(1), 38-49.

Yıldırım, M. H., Erul, E. E., \& Kelebek, P. (2014). Tükenmişlik ile işten ayrılma niyeti arasındaki ilişki banka çalışanları üzerine bir araştırma. Organizasyon ve Yönetim Bilimleri Dergisi, 6(1), 1309 -8039.

Yirik, Ş., Ören, D., \& Ekici, R. (2014). Dört ve beş yıldızlı otel işletmelerinde çalışan personelin örgütsel stres ve örgütsel tükenmişlik düzeyleri arasındaki ilişkilerin demografik değişkenler bazında incelenmesi. Journal of Yasar University, 9(35), 6099-6260.

Zincirkıran, M., Çelik, M. G., Ceylan, A. K., \& Emhan, A. (2015). İşgörenlerin örgütsel bağlılık, işten ayrılma niyeti, iş stresi ve iş tatmininin örgütsel performans üzerindeki etkisi: Enerji sektöründe bir araştırma. Finans Politik \& Ekonomik Yorumlar Dergisi, 52(600), 59-71. 
Zopiatis, A., Constanti, P., \& Theocharous, L. A. (2014). Job involvement, commitment, satisfaction and turnover: Evidence from hotel employees in Cyprus. Journal Tourism Management, 41, 129-140. 